INTERACTIVE ARTICLE COVER

RUPKATHA JOURNAL

About the Journal

\begin{tabular}{|c|c|}
\hline \multicolumn{2}{|r|}{ About the Journal } \\
\hline Journal DOI & https://doi.org/10.21659/rupkatha \\
\hline Journal Home & www.rupkatha.com $\oslash$ \\
\hline Indexed by & Scopus $\triangle$ Web of Science: Emerging Sources Citation Index (ESCI) DOAJ \\
\hline Journal Metrics & CiteScore 2020: 0.2 | SJR 2020: 0.162 | SNIP 2020: 0.193 | JCI 2020: 0.50 \\
\hline \multicolumn{2}{|r|}{ About the Issue } \\
\hline Themed issue & $\begin{array}{l}\text { Volume 4, number 1, } 2022 \text { (January-March) | Contemporary East and } \\
\text { Southeast Asian Literary and Cultural Studies }\end{array}$ \\
\hline Guest Editors & Dr Jeremy de Chavez $\oslash$ \& Dr Zhang Yue, University of Macau, China \\
\hline Issue DOI & https://doi.org/10.21659/rupkatha.v14n1 \\
\hline TOC & https://rupkatha.com/v14n1.php \\
\hline Peer Review & Under the responsibility of the Guest Editors \\
\hline \multicolumn{2}{|r|}{ About the Article } \\
\hline Title & $\begin{array}{l}\text { Women Trespassing Borders: Imaginaries of Cosmopolitanism from Below } \\
\text { in Mia Alvar's In the Country }\end{array}$ \\
\hline Author/s & Carlos M. Piocos III $凶$ \\
\hline Affiliation & Literature Department, De la Salle University, Manila, Philippines \\
\hline Author ID & https://orcid.org/0000-0003-3697-781X \\
\hline Funding & No funding received. Published free of any charge. \\
\hline Article DOI & https://doi.org/10.21659/rupkatha.v14n1.12 Pages: 1-11 \\
\hline Abstract & https://rupkatha.com/v14n112 \\
\hline Full-text PDF & https://rupkatha.com/V14/n1/v14n112.pdf 囚 \\
\hline \multirow[t]{3}{*}{ Article History } & Abstract received: 15 March 2021 | Complete article received: 23 May 2021 \\
\hline & Revised article received: 29 July 2021 | Accepted: 14 August 2021 \\
\hline & First Published: 05 February 2022 \\
\hline Article Impact & Check Dynamic Impact \\
\hline Copyright & Aesthetics Media Services $\square$ \\
\hline Licensing & Creative Commons Attribution Non-Commercial 4.0 \\
\hline
\end{tabular}

This Open Access article is published under a Creative Commons Attribution Non-Commercial 4.0 International License (http://creativecommons.org/licenses/by-nc/4.0/), which permits non-commercial re-use, distribution, and reproduction in any medium, provided the original work is properly cited. For citation use the DOI. For commercial re-use, please contact editor@rupkatha.com. 
1 | Rupkatha Journal, Vol. 14, No. 1, 2022

Research Article

\title{
Women Trespassing Borders: Imaginaries of Cosmopolitanism from Below in Mia Alvar's In the Country
}

\author{
Carlos M. Piocos III \\ Literature Department, De la Salle University, Manila, Philippines
}

\begin{abstract}
Mobility has been historically tied to conceptions of cosmopolitanism, bringing forward imaginaries of belonging-in-the-world and going beyond the narrow limits of parochial allegiances into embracing virtues of openness as global citizens shaped by the experience crossing borders and encounter with the Other. Despite dominant ideas about cosmopolitans as elite itinerants of middle-class intellectuals, artists, tourists, expatriates and capitalists, global migration with its entailing forms of mobilities from below-economic migrants, transmigrants, refugees, exiles - has redefined the term to include forms of minor and vernacular cosmopolitanisms that emerge among the migrant underclass. However, just like these forms of mobilities, these types of cosmopolitanism are also bound and shaped by class, gender and ethnicity. This paper explores versions of cosmopolitanism from below in the stories of Mia Alvar in her book, In the Country, that center on female domestic workers from the Philippines. Through the transnational itineraries of these border-crossing women protagonists in contemporary Filipino fiction, the article examines the intersections and contradictions of class, gender and race in cosmopolitan imaginaries of mobilities in Southeast Asia.
\end{abstract}

Keywords: mobilities studies, cosmopolitanism from below, migrant female domestic workers, Philippine contemporary fiction, Southeast Asian migration

\section{Introduction}

Immanuel Kant's classic concept of hospitality in receiving strangers and foreigners into one's thresholds and borders has become foundational in contemporary debates on migration, nationalism, and cosmopolitanism in the age of the ever-globalizing world (Bohman \& LutzBachmann, 1997). This Kantian ideals of cosmopolis is projected to bring about "a world in which people and novels and music and films and philosophies travel between places where they are understood differently, because people are different and welcome to their difference" (Appiah, 2005 , p. 258). This is why mobility, particularly that of diaspora, has been historically tied to conceptions of cosmopolitanism, bringing forward imaginaries of belonging-in-the-world, going beyond the narrow limits of parochial allegiances into embracing virtues of openness as global citizens shaped by the experience crossing borders and encounters with the Other (Appiah, 2006). But in contrast to Kant's idea that global commerce could bring about a more open and hospitable world towards foreigners, contemporary practices and discourses of globalization and migration have only exacerbated the borders that control and limit how people are invited, welcomed and accommodated according to their class, gender, race, and ethnicity (Cheah, 2006a). 
Beyond the laws, policies and norms that frame the extent to which people can enter and can be welcomed through borders, cosmopolitanism is about how people cross and transgress borders. Hence, the prevailing idea of cosmopolitanism comes to mean an emerging consciousness and practice of belonging to world through cultivation of an ethics of openness towards the Other that comes from the experience of travel and encounter with cultural diversity (Hannerz, 2005). But because venture capitalists, globe-trotting artists and cultural workers, tourists, immigrants, exiles, and refugees are all lumped together in the category of cosmopolitan class, this idea has been inclined towards the elite class itinerants and professional expatriates. This kind of cosmopolitanism from above tends to be too Eurocentric and Western-oriented overlooking the fact that much of the mobility of these diverse types of travellers are marked and differentiated by nationality, race and ethnicity, class and gender (Clifford, 1992). This dominant discourse of cosmopolitanism subsumes and erases the realities of majority of travellers who are precarious border-crossers like low-skilled, undocumented, or temporary migrants (Hall \& Werbner, 2008). Despite traditional conceptions of cosmopolitans as elite itinerants of middleand upper-class intellectuals, artists, tourists, expatriates and entrepreneurs, global migration with its entailing forms of mobilities from below-economic migrants, transmigrants, refugees, exileshas redefined the term to include forms of minor and vernacular cosmopolitanisms that emerge among diasporic, migrant and working-class subjects (Werbner, 1999, 2006). For Pheng Cheah (2019), these contemporary shifts in global migration offer a different order of diasporic worldliness, one that compels us to challenge traditional associations of travel with cosmopolitanism with the rise of these new and more prevalent figures of travelers. Studying narratives that portray these types of mobilities compel us to look into how dimensions of class, gender, race and ethnicity inflect notions of living together in difference and belonging-in-theworld (Werbner, 2014).

This paper explores versions of cosmopolitanism from below in contemporary Philippine Anglophone fiction, particularly in the short stories of Mia Alvar (2015) in her debut collection, In the Country through an examination of her portrayal of female domestic workers from the Philippines who traverse borders and stake their claims in cosmopolitan cities in Southeast Asia, Middle East, and Northern America. Alvar's short stories entitled, "Shadow Families" and "Esmeralda," dwell on the stories of Filipina domestic workers in Bahrain and New York, who not only trespass borders, but also transgress class lines to claim their place in these host cities. Through the transnational itineraries of these border-crossing female protagonists in contemporary diasporic Filipino fiction, the article examines the intersections and contradictions of gender and class in cosmopolitan imaginaries of mobilities in Southeast Asia.

\section{Narrating cosmopolitanism from below in Filipina women's diaspora}

Mia Alvar was born in the Philippines, grew up in Bahrain, then settled in New York. Her first book, In the Country, which won a PEN/Robert Bingham Prize for Debut Fiction, is composed of nine stories, two of which focuses on Filipina domestic workers in Bahrain and New York. The stories in this anthology conjure a world shaped by the vestiges of colonialism and effects of uneven globalization as her fiction imagines the lives of her fellow Filipinas in diaspora across the class 
lines, those who are perpetually displaced but constantly finding their own footing in these newfound cities.

Told from the perspective of an unnamed narrator, "Shadow Families" dwells on the fellowship of urbane middle-class housewives of Filipino professionals in Bahrain who are living in their blissful domestic lives in their ethnic enclaves as white-collar immigrants in the Middle East. This was especially highlighted during their weekend social gatherings, where they invite fellow Filipina women working as domestic workers in the foreign city, to alleviate their nostalgia and homesickness through weekly bonding over karaoke parties while also affirming their social status over their more marginalized compatriots in the desert country. However, their happily set lives are disrupted by the entry of a Filipina helper named Baby, who refuses to play along with the scripts of social etiquette cultivated in the little Manila these housewives have built in the Middle East. Baby's rejection of the role shaped by the class and gendered dimensions of her mobility has not only upset the dynamics of these community of migrant women but also completely upended their little bubble abroad, making them rethink the ways in which their class backgrounds have narrowed down, instead of opened up, their view of the world.

The story of the titular character in "Esmeralda," on the other hand, essays the life of a nighttime cleaner in New York, whose life has revolved around making a living to support her family back in the Philippines, surviving through the hardships of undocumentation and carving a pathway to citizenship in America by offering her service labor. Esmeralda's life would open up beyond the confines of her struggles for survival as an immigrant domestic worker because of her encounter with a white American office worker, John, who offers new ways of belonging in the world through the modes of encounter in difference. Told in the second person, the story interrogates and challenges ideas of belonging in America deeply divided along class and racial lines by imagining how profound encounters with the Other can provide a form of cosmopolitan vision for a lower-class migrant woman.

In Alvar's fiction, the figure of migrant female domestic worker brings forth important dimensions of gender and class differences in the discussion of cosmopolitanism. Both Baby and Esmeralda are cosmopolitanized by their transnational mobility as they belong to "non-elite forms of travel and trade in the postcolonial world" as economic migrants while also feminizing the usual masculinized imaginaries of worldliness as underprivileged women living on the margins that engage in cosmopolitan practices (Werbner, 2008, p. 14). As women practicing a form of cosmopolitanism from below, they are "driven across borders and uprooted from their homelands," to survive in places where they "live in translation" as they bear the effects of "combined and uneven globalization" because their mobilities are excluded from pathways created by global capital for those who belong to "cosmopolitans of the above" (Hall \& Werbner, 2008, p.346).

In his study of the tensions and contradictions of cosmopolitanism and human rights, Pheng Cheah (2006b) forwards two kinds of cosmopolitan figures in the age of truncated globality: the high cosmopolitanism - "the high-end cosmopolitanism of talented professionals"—and low cosmopolitanism, the everyday cosmopolitan social practices of "the underclass foreign domestic helpers who are the disavowed support of the aspiring global city" (p. 199). While the category of high and low in cosmopolitanism stresses the social class hierarchies embedded in transnational 
mobilities, the topographical classification of cosmopolitanism from above and below highlights the conflicting social practices of belonging that these social class divides engender in the globalized world.

Christopher Patterson (2012) discusses these tensions of multiple versions of cosmopolitanism in his examination of class, ethnic belonging, and cosmopolitan aspirations in Filipino American novels that portray middle-class Asian Americans who consume the labor provided by precarious Asian immigrant service workers. In his analysis of Han Ong's novels, Patterson claims that while low cosmopolitans aspire for global belonging by offering their service work in America, the high end cosmopolitanism of their wealthier compatriots desire and consume that labor to garner ethnic and cultural authenticity. This is why, for Patterson, "cosmopolitan identity is never simply a matter of culture or migration but is under constant negotiation by the subject's mobility, class position, and production or consumption of affective labor" (p. 100). It is important then to examine the contradictions of class differences that not only produce truncated and unequal globality but open new versions and figures of cosmopolitanism.

\section{Gendered mobilities and class divides}

The tension between high and low cosmopolitanism, brought about by class differences, is also an important feature in Alvar's fiction. Yet unlike Ong's novels, these narratives portray a kind of low cosmopolitanism of migrant Filipina domestic worker characters that resist easy appropriation and consumption by the high cosmopolitanism of the wealthier fellow Filipinos in diaspora.

This divide among high and low cosmopolitans is evident in Alvar's story, "Shadow Families," between the group of expatriate white-collared Filipino housewives and the group of blue-collared Filipino domestic helpers in Bahrain. The narrator describes her little band of housewives as "the lucky ones," because "despite the advanced degrees [they'd] collected and resumes [they'd] built back home, [they] spent [their] days baking cakes and hanging curtains" because they have "married engineers, doctors, diplomats, and executives, who earned enough" to keep them at home (Alvar, 2015, p. 94). As middle-class expats in Bahrain, they never really got or felt the need to integrate in their host society, seeing themselves only there at the "pleasure of people who mystified [them]" (p.93), welcomed to stay but never really felt at home in their new place: "We'd arrived on their island like the itinerant father in the fairy tale about a beauty and a beast, our houses fully furnished by some unseen master... We lived like villagers at the foot of a volcano, hoping never to offend the gods who governed our harvest and our wealth" (p.94).

Unlike them, the "other women," occupying the other end of cosmopolitanism, who had come to work in the same country "to clean floors or mind rich people's children" (p.94), are compelled to find their own footing inside the houses of their foreign employers, since they work in their host's private and domestic spaces:

These katulong -'helpers,' as we called them-were often younger but always aging faster than we were, their skin leathering from the desert sun, their spines hunching over brooms and basins, their lungs fried by bleach and petroleum vapors. They lived not with spouses or children but with each other, five or six katulong to a flat. Or else, they lived with employers, who kept their passport and work contracts under lock and key (p.95). 
The Filipina helpers are invited by the middle-class Filipina housewives in their weekly parties because being with them gives them a sense of intimacy to their homeland. However, this feeling of homeliness that comes from the kind of ethnic identity that the low cosmopolitans share with high cosmopolitans and the familiarity in the helper's presence is inflected by class: "The helpers came from farming provinces, like our fathers. They spoke Tagalog with country accents, like our mothers. Our parents too had fled droughts and typhoons in their youth, hoping for a steady servant work in Manila. Helping these helpers, who'd traveled even farther, felt like home" (p.95). The narrator and her friends clearly see their shared mobilities and its entailing gendered plight as providers of affective labor and care work, both paid and unpaid, yet their affinity to these women are cleaved by their class backgrounds, as the high cosmopolitans only see in the low cosmopolitans traces of class barriers they and their own families have, throughout the years, succeeded to surpass through upward social mobility.

This, however, is more than just an interaction between middle and lower class women. Through the prism of encounter of high and low cosmopolitans, the lines of their affinity and division in their social practices of mobility and belonging, in spite and despite of their social class, are also brought forth in these social events. Brought together by their shared ethnic origins and gendered domestic struggles yet divided by their economic status, both of these groups of cosmopolitan Filipino women ambivalently navigate these social gatherings where they both find solidarity in their shared isolation in the desert country while also maintaining social class hierarchies.

The social dynamic within this enclave of Filipino women in the desert country is suddenly unsettled with the introduction of Baby in their community. While they expected "someone just like them: another sweet, humble church mouse, who'd somehow strike us as child and granny all at once" (p.95), the new helper wears provocative clothes and translucent high heels to their parties, refuses to speak Tagalog even among her fellow Filipinos, and insists on speaking in her jagged English with her provincial accent. Moreover, Baby does not subscribe to the invisible and unwritten social codes of class enforced by the narrator and her friends unto the women of her rank in Bahrain, but has instead turned over the role of doting helper to the wealthier women who are hosting her out of their generosity: "Baby wasn't waiting for permission. She peered past us to the living room, as if entering a shop instead of a home... When at last she turned to us, we felt like saleswomen who'd kept her from browsing the shelves in peace" (p.96).

The story then dovetails into the many transgressions of Baby within this little diasporic community through the eyes of the middle-class migrant housewives. The new helper in the island clearly subverts the stereotypes of migrant woman underclass in Bahrain as she projects a kind of aspirational lifestyle that seems out of reach for a low cosmopolitan like her. Through her housemates, they learn that unlike her fellow Pinay maids who look plain and live modest, unassuming lives, she is vain and eccentric, hoarding and displaying luxury make-up and clothes even when she is toiling inside the rich Arab homes of her employers. They would also chance upon her in public, acting like a wealthy wife of Bahraini oil magnate as she dresses up in expensive abayas and goes on shopping sprees even though her salary clearly could not afford such lavish habits. In their weekly parties which she starts attending less and less, she continues to refuse to display deference to the middle-class women who invites and feeds her, much to the chagrin of the group. Later on, they find out that Baby is pregnant, which led the narrator and her friends to 
Women Trespassing Borders: Imaginaries of Cosmopolitanism from Below in Mia Alvar's In the Country

rush to her help only to be rejected by Baby, who seems to sense that the group of privileged migrant wives are only subtly reinforcing their moral and social authority over her. In the story's climax, the women confronted her about the father of her baby in the guise of helping her resolve her work visa crisis. Baby rebuffs their offer and instead playfully hints that the one impregnated her could be anyone of their husbands.

With Baby sowing the seed of suspicion, the middle class housewives are sent into a spiral of rumor-mongering and internal conflicts, not just between them and their husbands but also within their supposedly solid group of friends. Even after Baby leaves the island, which brought relief to the narrator and her friends, their weekly parties have never been the same. "In Baby's wake, we shrank a little from routine, from rituals that might invite disruption. We were a little warier, too, of the katulongs who came to our houses to share our food and accept our hand-medowns. For the first time they seemed capable of harming us" (p. 117).

However, the harm that Baby has brought to the lives of these high cosmopolitan women becomes less and less insidious as the realization of how limited and limiting the world that these middle class migrant housewives has built in Bahrain has gradually dawned upon them as time goes by and as they move on with their lives in the Middle East and beyond. With Baby's disruption to their quiet little bubble in diaspora, they also started venturing forth into a much open and less certain territories beyond their small ethnic enclave in the desert country. As they go on "transnational drift" (p. 118), transferring from Bahrain to Europe and America, they begin to experience some of the struggles of their fellow migrant women like Baby and the other helpers, who are less privileged and more marginalized in their newfound places in the world:

We moved into apartments whose leaks and leases we would have to handle on our own; we lay awake in single beds, sensing that we'd snipped a cord not just from home but from the law of gravity itself, and if we tumbled off the planet altogether no one, for a while, might know.

What all this did was get us to thinking again, for the first time in years, about Baby, the woman who had once been enemy and outcast to us. Now we were outcasts, of a certain sort, as well. Time had toppled our pillars of domestic and family life without her help. It might be overstating things to say we've walked a mile in Baby's high-heeled shoes; we had advantages she didn't, after all, to ease our lonely exile from the land of perfect wifeand motherhood. But now we do know something, do we not, of what it is to be the woman other woman hope not to become? The world's so big, it has exploded our old ideas, and we're not the people who condemned her then (p. 119).

The encounter with Baby, and the many ways in which she subverts the class codes of migrant women in diaspora have enlarged the world and the worldview of the narrator and her group of middle-class migrant wives. Baby represents not just the pleasures of transgression to their illusory middle class comfort, but also a form of unassimilable agency of lower class mobility that aspires and actively enacts her aspiration to belong in a global city without the baggage of privilege and middle class respectability. While the gendered and class divides that exist among the diasporic community are still in place, along with the structures of inequality that structure the hierarchy between high and low cosmopolitans among Filipino women in the desert country, Baby's 
trespasses to the invisible borders of class have also compelled the women to challenge their own notions of middle class respectability and position that only shrink their world and pull them back to their safe spaces even in diaspora, away from possible contact zones where encounters with difference can make them more cosmopolitan beyond their privilege. Meeting a low cosmopolitan woman like Baby whose refusal for her marginalized presence and labor to be consumed and appropriated by the group of high cosmopolitans proved to be a much more radical and transgressive imaginary of cosmopolitanism, one that explodes old ideas, enlarges one's world and also allows one to become more welcoming to difference by cultivating empathy towards the disavowed other. Baby, the subversive low cosmopolitan, invites a view of cosmopolitanism from below where migrant underclass women like her has to actively trespass class, racial and gendered lines to find their own footing in foreign lands and create their own versions of belonging. The high cosmopolitan women's recognition of Baby's transgressions illustrates their new perception of an expanded vocabulary of cosmopolitan agency forged by a deeper affinity and identification to difference.

\section{Encounters with Difference}

This encounter with the Other is an important pathway towards a more embracing form of cosmopolitanism, something that can also be seen in Alvar's work, "Esmeralda," which centers into the life and struggles of a Filipina nighttime cleaner in New York, who meets and falls in love with an American office worker in one of the buildings where she works. Unlike "Shadow Families," the story employs a second person point of view that compels the reader to be attached with the perspective of Esmeralda, and see New York through her eyes, despite the difference of the class position of the reader who are presumably middle to upper class consumers of fiction. In her reflection on her use of this point of view in writing this story, Alvar is aware that there will be an inherent resistance from the readers to connect more closely to a stranger's perspective, yet she felt that she has "to insist that 'you' imagine yourself into Esmeralda's life... to call attention to both the necessity and the difficulty of truly identifying with someone you don't know" (Lee, 2015).

This kind of strategy that Alvar deploys to enforce empathy through narratology is a form of cosmopolitan narrativization that Narendra Kumar (2012) refers to as inter-narrativity: "a narrative strategy of cutting across diverse cultural, racial and ethnical borders to bring out metonymic identification of experiences... through juxtaposition and inter-twining of diverse experiences" (p. 229). In the story, the readers, who are addressed as the 'you' that identifies with Esmeralda's point of view, get to be familiar to the place where she comes from and why she migrated-"Being a girl-a poor and dark one, no less-you wouldn't dare dream these things for yourself. You left school at thirteen to help with the coconuts and Pepe's chances" (Alvar, 2015, p.162) - and the daily strife she faces to survive through her years as an undocumented migrant to her more stable, yet never easier, life as immigrant service laborer in the U.S.—“Nineteen years of cash in envelopes, from people who never asked to see your papers as long as you had references and kept their sinks and toilets spotless" (p.158). The inter-narrativity of the second person perspective here opens up the possibility for readers to have a meaningful encounter with the character's rich inner life and history, placing the reader into the place of difference by narrating the everyday struggles of Esmeralda as a low cosmopolitan trying to survive in America. 

In the Country

Just like Alvar's "Shadow Families", this story also sets up the low cosmopolitan character to cross paths with a middle class character in John, a white-collared American worker in the office that Esmeralda cleans every night. Yet unlike the initial disavowal of high cosmopolitans to the Filipina helper in the previous story, "Esmeralda" portrays a much more welcoming stance to class and racial differences: John seeks the comforting presence of the stranger in the office during the wee hours of the night, while Esmeralda, although cautious at first, would learn to accept the privileged Other's intrusion into her hectic workhours as a lady cleaner. In one of their first few encounters, after opening up to John about her everyday life and routine as an immigrant bluecollared worker in their office, Esmeralda learns of the man's struggles of having to support his cancer-stricken wife after asking about the picture of a woman on the man's desk she routinely wipes at night:

Before John-and this is terrible to say; you'd never say it, but-the lives of Americans with money were not very interesting to you. Even the troubled ones, their troubles did not seem so hard. You'd ask, "How are you?" and they'd heave a sigh, winding up to tell you some sob story: how much they worked, who had it in for them, the things they'd wished for and were not getting. Try hunger. Try losing your house, a voice inside you, that would never leave your mouth of course, wanted to say. But John's trouble-that moved you ( $p$. 160).

Esmeralda, who has been confined to her daily grind as a service worker, harbored a view of the world that is also constrained by her position of disenfranchisement as a working class woman of color. However, meeting and getting to know John, a white middle class man of relative privilege who has also attempted to get to know her more beyond her designation as the nighttime cleaner in his office, opened her understanding of other people's struggles. This encounter with difference is important in cosmopolitanizing Esmeralda's worldview, as she also starts to step outside her own class, racial and cultural biases. As Kumar (2012) claims, the internarrativity of this encounter with difference cultivates "empathy [that] enables a person to navigate through various cultural borders and rigidities to comprehend diverse systems of cultural syntax and semantics [to build] cross-cultural linkages for the co-existence and co-habitation of diverse cultures" (p.229). This narrative strategy of difference then cultivates empathy that fosters deeper understanding to the other, whether they be the disavowed or the privileged ones in cosmopolitan network of global labor.

Alvar further explores the inter-twining of experiences and struggles of Esmeralda and John through the use of dialogues. Their conversations, first as casual friends which led to a brief love affair, and then after separation, as close confidant to each other, signal the points of convergence and mediation of differences. During their late night meetings, John would allow Esmeralda to take naps on his couch while he does the cleaning for the protagonist. Then after the office is cleaned and the cleaner has fully rested, they would exchange stories about their very different lives and dreams as estranged citizens of the city. The story examines the inter-narrativity of these two very different characters through these late night conversations, as the dialogues between Esmeralda and John becomes a locus of exchange, where their difference becomes both a site for conflict and negotiation. In one of their intimate exchanges, Esmeralda shares to John 
why she is trying to make it in the city to sustain her family back home in the Philippines, which has provoked a curious response from the man:

"I'm sorry." John gave you the same eyes Doris did, when she asked if you got tired of supporting all those people. Doesn't it get heavy, Esmeralda-the weight of the world?

You shrugged. "I think having no one to lean on you is worse" (Alvar, 2015, p. 166).

This conversation reveals how attachments like obligations to homeland and rootedness can be part of the ways in which low cosmopolitan figures, like economic migrants like Esmeralda, construct ideas of worldliness. The heaviness of Esmeralda's responsibilities to her family back in the Philippines can be both constricting, as it shapes her economic duties as migrant but it also is also something which gives her a claim to her place out in the open world. This version of cosmopolitanism from below radically ruptures the dominant imaginaries of "rootless cosmopolitanism" which "invokes a kind of cultureless, rootless image of a person who is freefloating, sampling all the cultures like my global entrepreneurs" (Hall \& Werbner, 2008, p.353). In Esmeralda's case, the 'weight of the world' in sustaining her whole clan back home gives her a foothold in a cosmopolitan city like New York because attachments and rootedness can provide a different vision and practice of worldliness.

The story then unfolds to show how Esmeralda and John's deep friendship would end during the attack on the World Trade Center, the iconic site of historical trauma where both of these minoritized characters work and meet each other every night. The protagonist rushes to the site of attack in search of her friend who she suspects might already be buried in the skyscraper's rubbles. The story however did not end in this tragedy as the last pages shuttle back to the past, back when Esmeralda and John are still in their brief affair. In this intimate scene when the couple are sharing how their fates entwined at the right moment at the same building and in the same city, John commends how brave Esmeralda is for trying to survive in New York and not quitting to go back to her homeland, despite all the challenges she faced throughout her years as a lowwaged worker. Esmeralda answers with a kind of hopefulness, that is no longer about survival, but about a sense of an openness to a yet unforeseen future: "You told him somehow you weren't finished with the city. Something kept you here. The city wasn't done with you" (Alvar, 2015, p.189). These last lines in the story invoke a kind of relationality of the low cosmopolitan to her claim and stakes to a place. While the readers might see this as a continuance of survival strategies for the migrant working underclass, it also gives glimpses of an opening to a future of belonging and homeliness to a world, a way of claiming the promise of finally earning her place in the cosmopolis through her presence and labor.

\section{Conclusion}

Mia Alvar's In the Country dwells in these moments of encounters with difference. In "Shadow Families," the middle class women in diaspora are confronted with a figure of a low cosmopolitan, who rejects the kind of tribalism that the narrator and her friends breed in the island. In "Esmeralda," the low cosmopolitan protagonist encounters a middle class local, who opens her world beyond her disposable lifeworld as precarious immigrant service worker in the city. Through these points of exchange that are stirred by migrant working class women crossing and 
trespassing of geographical and social borders in the cosmopolis, Alvar portrays the complex workings of the dimensions of gender, race and class in the mobilities of global network of labor to construct the rich inner worlds and world-making capacities of cosmopolitans from below. These stories also revel in uncertainties and open-ended futures that expresses the kind of "cosmopolitan hope" that comes "upward from below" rather than "imposed downward from high" (Gilroy, 2005, p.67). The high cosmopolitan migrant Filipina housewives in "Shadow Families," transformed by their encounter of a rebellious Filipina maid, saw themselves pushed into the precarious terrains that their disavowed other have crossed and survived crossing, only to grow into finding their own foothold in a world without their previous attachments and privileges. And the low cosmopolitan protagonist in "Esmeralda" finds a new lease of life beyond her lifetimes of disposability and precarity as immigrant service laborer to invoke an open-ended future of finally belonging in the city by developing empathy and affection towards the privileged other.

\section{Declaration of Conflict of Interests}

The author(s) declared no potential conflicts of interest.

\section{Funding}

No funding has been received for the publication of this article. It is published free of any charge.

\section{References}

Alvar, M. (2015). In the country: stories. Alfred A. Knopf.

Appiah, K. A. (2005). The Ethics of Identity. Princeton University Press.

Appiah, K. A. (2006). Cosmopolitanism: ethics in a world of strangers. W. W., Norton \& Company, Inc.

Bohman, J., \& Lutz-Bachmann, M. (1997). Perpetual Peace: Essays on Kant's Cosmopolitan Ideal. MIT Press.

Cheah, P. (2006a). Cosmopolitanism. Theory, Culture \& Society, 23(2-3), 486-496.

Cheah, P. (2006b). Inhuman Conditions: On Cosmopolitanism and Human Rights. Harvard University Press.

Cheah, P. (2019, January 14, 2019). Diasporic Worldliness in Postcolonial Globalization [Lecture]. National University of Singapore. https://ari.nus.edu.sg/events/diasporic-worldliness-in-postcolonialglobalization-by-prof-pheng-cheah/

Clifford, J. (1992). Travelling cultures. In L. Grossberg, C. Nelson, \& P. Treichler (Eds.), Cultural Studies. Routledge.

Gilroy, P. (2005). Cosmopolitanism Contested. In Postcolonial Melancholia (pp. 58-86). Columbia University Press.

Hall, S., \& Werbner, P. (2008). Cosmopolitanism, Globalisation and Diaspora. In P. Werbner (Ed.), Anthropology and the New Cosmopolitanism: Rooted, Feminist and Vernacular Perspectives (pp. 345-360). Berg.

Hannerz, U. (2005). Two faces of cosmopolitanism: culture and politics. Statsvetenskaplig tidskripft, 107(3), 199-213. 
Kumar, N. (2012). Cosmopolitanism, Inter-narrativity and Cultural Empathy: Caryl Phillips' The Nature of Blood and Zadie Smith's White Teeth. Rupkatha Journal on Interdisciplinary Studies in Humanities, $4(2), 228-235$.

Lee, J. (2015). What's Lost and What's Gained, a conversation with Mia Alvar, author of In The Country. Electric Literature. Retrieved April 15, 2021, from https://electricliterature.com/whats-lost-andwhats-gained-a-conversation-with-mia-alvar-author-of-in-the-country/

Patterson, C. B. (2012). Cosmopolitanism, Ethnic Belonging, and Affective Labor: Han Ong's Fixer Chao and The Disinherited. WorkingUSA, 15(1), 87-102. https://doi.org/https://doi.org/10.1111/j.17434580.2012.00374.x

Werbner, P. (1999). Global pathways: Working class cosmopolitans and the creation of transnational ethnic worlds. Social Anthropology, 7(1), 17-35.

Werbner, P. (2006). Vernacular Cosmopolitanism. Theory, Culture \& Society, 23(2-3), 496-498.

Werbner, P. (2008). Introduction: Towards a New Cosmopolitan Athropology. In P. Werbner (Ed.), Anthropology and the New Cosmopolitanism: Rooted, Feminist and Vernacular Perspectives (pp. 1-29). Berg.

Werbner, P. (2014). Cosmopolitanism: Cosmopolitan Cities and the Dialectics of Living Together with Difference. In D. M. Nonini (Ed.), A Companion to Urban Anthropology (pp. 306-326). John Wiley \& Sons, Ltd.

\section{Author's bio-note}

Carlos M. Piocos III is a professor at Literature Department and a research fellow at Southeast Asia Research Center and Hub of De La Salle University. His main research interests are cultural studies, Southeast Asian literature and film, and gender and migration studies. E-mail: carlos.piocos@dlsu.edu.ph. 